\title{
Inverted Follicular Keratosis in External Auditory Canal: Case Report and Literature Review
}

Bruno Amaral Hay ${ }^{1,2}$, Juliana Cristina Mesti ${ }^{1,2}$, Juliana Mattos Baretta ${ }^{1,2}$, Lorena Cristina Gomes ${ }^{1,2}$, Ana Luiza Camargo $^{1,2}$, Andreza Formiga ${ }^{1,2}$, Gilberto Da Fontoura Rey Bergonse ${ }^{2}$, Ana Paula Chornobay ${ }^{1,2}$, Rodrigo Marques

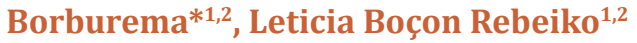

${ }^{1}$ Centro de Estudos Otorrinolaringológicos Lauro Grein Filho, Curitiba/PR, Brasil

${ }^{2}$ Departamento de Otorrinolaringologia do Hospital da Cruz Vermelha Brasileira, Curitiba/PR, Brasil

Submission: August 13, 2018; Published: August 22, 2018

*Corresponding author: Rodrigo Marques Borburema, Rua Visconde do Rio Branco, 1102, Mercês, Curitiba-PR, Brazil, Tel: +5541992122503;

Email: rodrigo.borborema@yahoo.com.br

\section{Abstract}

Objective: we report a rare case of inverted follicular keratosis in external auditory canal. Method: case reports and review of the world literature concerning inverted follicular keratosis in external auditory canal.

Keywords: Inverted follicular keratosis (Ifk); External auditory canal (Eac); Benign tumor

\section{Introduction}

Inverted follicular keratosis (IFK) appears as a firm, asymptomatic, pinkish-brown, usually small (less than $1 \mathrm{~cm}$ in diameter) papule. It is located in the face region in about $85 \%$ of cases, especially in the chin and upper lip, other sites of the head and neck can also be affected. It reaches males more often thanfemales and they are usually middle-aged and elderly individuals[1,2]. Histologically it may be classified as a benign tumor of the infundibulum of the hair follicle, although the cause of the onset of this lesion has not yet been fully elucidated[3]. It is characterized by large lobules that extend to the dermis, composedof basaloid cells in the periphery and squamous keratinized cells towards the center with scaly swirls [4]. Some authors postulate that it may be related to viral warts or seborrheic keratosis, others believe that it is an independent entity $[5,6,7]$. In one study, no inverted follicular keratosis was found in the human papilloma virus, militating against a relationship with viral warts[8]. Dermatoscopy is not enough to establish the diagnosis and to differentiate it from other lesions related to more frequent pathologies, such as viral warts, seborrheic keratosis, basal cell carcinoma (BCC) and squamous cell carcinoma (SCC), being necessary the anatomopathological study for definitive diagnosis [8]. The most common method used in the treatment of inverted follicular keratosis is complete surgical excision. After caution surgical excision, there is no evidence of invasive growth or metastasis[9].

\section{Case Report}

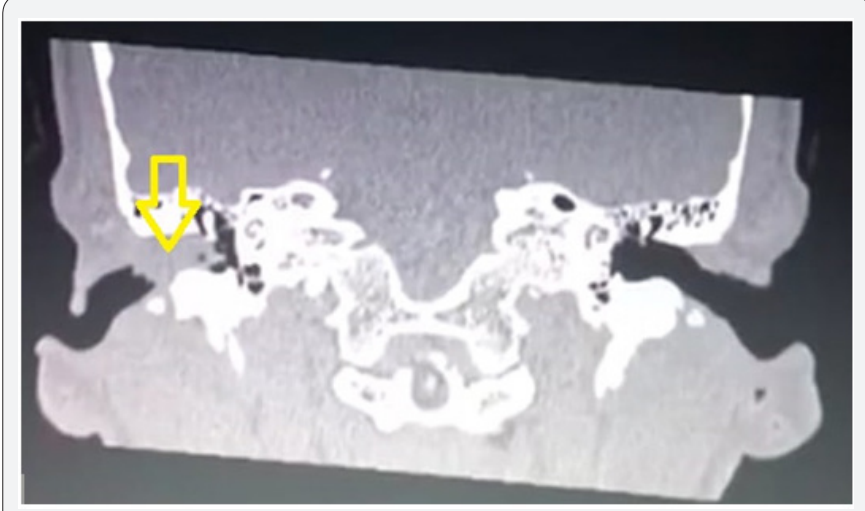

Figure 1: Soft-tissue material was evidenced in the external auditory canal (arrow).

A 35-year-old female patient was seen in the otorhynolaryngology department with sintomns of a longstanding otorrhea. Physical examination revealed a verrucous and bleeding lesion in an external auditory conduit with progressive growth for three years. The audiometry did not show hearing loss and the immitance tympanometry showed a type A tympanometry curve on the left side and type as on the right side. On the tomography, soft-tissue material was evidenced in the external auditory canal, causing partial obstruction of the 
right conduit (Figures 1\&2). Middle ear, mastoid and left ear without changes. The patient underwent surgical resection of the lesion and the histopathological analysis of the fragments revealed the diagnosis of inverted follicular keratosis (IFK).

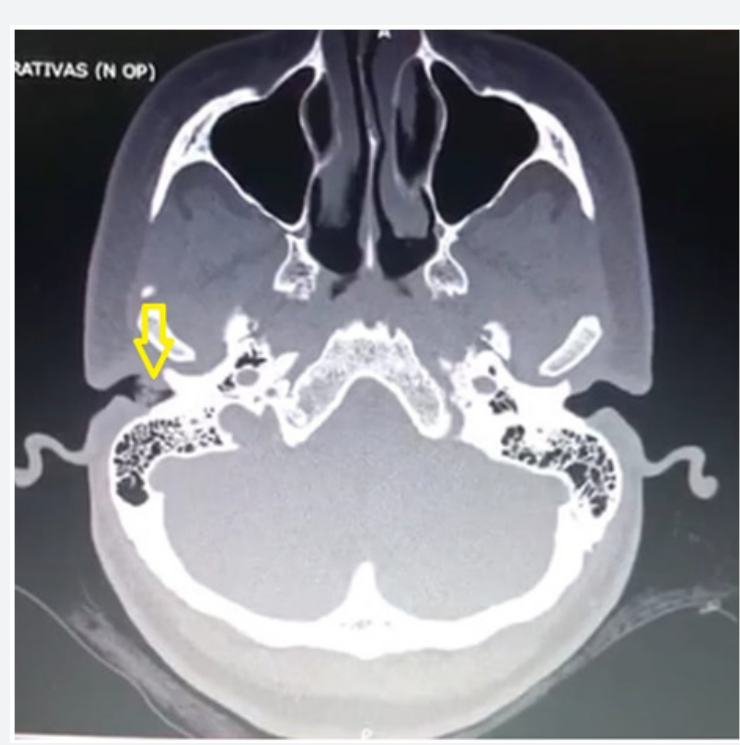

Figure 2: Soft-tissue material was evidenced in the external auditory canal (arrow).

\section{Discussion}

The presentation of inverted follicular keratosis in the external auditory canal (EAC) is extremely rare and therefore often unknown.The pattern reversed in the EAC has a high risk of erroneous interpretation as an invasive tumor dissemination, making anatomical pathological analysis mandatory fordifferentiation [10]. The IKF has chromatic variants, having relation with the melanin cellular content, being more common brown and yellow colorations. Although expansive lesions in EAC commonly cause conductive hearing loss [11,12], there was no loss in this case. The tomographic study assisted in the evaluation of the lesion and a complete surgical excision of the lesion was performed. The development of secondary degenerations are extremely rare but described in the literature
[13]. The histopathological analysis differentiated it from other pathologies. After the result, excision of the lesion - treatment of choice for inverted follicular keratosis-had already been performed [9]. There was no need for another complementary treatment because there is no evidence of malignancy.

\section{References}

1. Bolognia J (2015) Dermatologia 3a edição. Elsevier Brazil p1806.

2. Soylu L, Akcali C, Aydogan LB, Ozsahinoglu C, Tuncer I (1993) Inverted follicular keratosis. American journal of otolaryngology 14(4): 247248.

3. Battistella M, Peltre B, Cribier B (2010) Composite tumors associating trichoblastoma and benign epidermal/follicular neoplasm: another proof of the follicular nature of inverted follicular keratosis. Journal of cutaneous pathology 37(10): 1057-1063.

4. Weedon D (2010) Tumors of cutaneous appendages. In: Weedon D (Eds.), Weedon's Skin Pathology, $\left(3^{\text {rd }} e d n\right)$, Amsterdam, Netherlands pp.765-766.

5. Vázquez K M, Olivera R M P (2009) Queratosis folicular invertida: Comunicación de dos casos. Dermatología Revista Mexicana 53(4): 190-194.

6. Mehregan AH(1983) Inverted follicular keratosis is a distinct follicular tumor. Am J Dermatopathol 5:467-470.

7. Ruhoy S M, Thomas D, Nuovo G J (1991) Multiple inverted follicular keratoses as a presenting sign of Cowden's syndrome: case report with human papillomavirus studies.

8. Hori K (1991) Inverted follicular keratosis and papillomavirus infection. Am J Dermatopathol 13:145-151.

9. Schweitzer J G, Yanoff M (1987) Inverted follicular keratosis: a report of two recurrent cases. Ophthalmology 94: 1465-1468.

10. Halleck P, Loddenkemper C, Hummel M et al.(2009) Hyperkeratotic Inverted Seborrheic Keratosis of The Outer Auditory Canal: A First Description HNO 57: 480-483.

11. Hafner C, Vogt T (2008)Seborrheic keratosis. J Dtsch Dermatol Ges 6: 664-677.

12. Magliulo G, CiniglioAppiani M (2011)Seborrheic keratosis, keratotic type, of the external auditory canal. Otolaryngol Head Neck Surg 145:697-698.

13. Murphy G F, Elder D E (1991) Seborrheic kerato- sis. In: Rosai J (Eds.), Atlas of tumor pathology. Non- Melanocytic tumors of the skin. $3^{\text {rd }}$ series, AFIP, Washington DC, p. 13-19.

\section{Your next submission with Juniper Publishers will reach you the below assets}

- Quality Editorial service

- Swift Peer Review

- Reprints availability

- E-prints Service

- Manuscript Podcast for convenient understanding

- Global attainment for your research

- Manuscript accessibility in different formats

( Pdf, E-pub, Full Text, Audio)

- Unceasing customer service

Track the below URL for one-step submission https://juniperpublishers.com/online-submission.php 